\title{
Prevalence of anti-Toxoplasma gondii and anti-Neospora caninum antibodies in swine from Northeastern Brazil
}

Prevalência de anticorpos anti-Toxoplasma gondii e anti-Neospora caninum em suínos do Nordeste do Brasil

\author{
Sérgio Santos de Azevedo ${ }^{1}$; Hilda Fátima de Jesus Pena ${ }^{2}$; Clebert José Alves ${ }^{1}$; \\ Antônio Alfredo de Melo Guimarães Filho'; Robério Macedo Oliveira'; Pavlo Maksimov; \\ Gereon Schares ${ }^{3}$; Solange Maria Gennari ${ }^{2 *}$
}

${ }^{1}$ Unidade Acadêmica de Medicina Veterinária, Centro de Saúde e Tecnologia Rural,

Universidade Federal de Campina Grande - UFCG

${ }^{2}$ Departamento de Medicina Veterinária Preventiva e Saúde Animal, Faculdade de Medicina Veterinária e Zootecnia, Universidade de São Paulo - USP

${ }^{3}$ Friedrich-Loeffler-Institut, Federal Research Institute for Animal Health, Institute of Epidemiology

Received September 21, 2009

Accepted October 22, 2009

\begin{abstract}
A serologic survey was conducted among 130 swine slaughtered in the public slaughterhouse of the city of Patos, Paraíba State, Northeastern Brazil, to determine the prevalence of anti-Toxoplasma gondii and anti-Neospora caninum antibodies, and to verify possible associations between sex of the animals and antibody prevalence. The sera were analyzed by indirect antibody tests, considering 1:64 (T. gondii) and 1:50 (N. caninum) dilutions as cut-off points. The prevalence of anti- $T$. gondii antibodies was $36.2 \%(47 / 130)(95 \% \mathrm{CI}=27.9-45.0 \%)$ with reciprocal titers ranging from 64 to 2,048, and of anti- $N$. caninum antibodies was $3.1 \%(4 / 130)(95 \% \mathrm{CI}=0.8-7.7 \%)$ with reciprocal titers ranging from 50 to 6,400 . Three of the four $N$. caninum-positive samples were also positive for $T$. gondii antibodies. All Neospora and Toxoplasma IFAT-positive animals were also positive for confirmatory immunoblotting techniques using total and purified $N$. caninum and T. gondii tachyzoite antigens, i.e., p38 (NcSRS2) and p30 (TgSAG1). There was no association between sex of animals and prevalence of anti-T. gondii and anti- $N$. caninum antibodies. This is the first indication of $N$. caninum natural infection in pigs from Brazil.
\end{abstract}

Keywords: Swine, Toxoplasma gondii, Neospora caninum, seroprevalence, Northeastern Brazil.

\section{Resumo}

Foi conduzido um estudo sorológico em 130 suínos abatidos no matadouro público do município de Patos, Estado da Paraíba, Nordeste do Brasil, com o objetivo de determinar a prevalência de anticorpos anti-Toxoplasma gondii e anti-Neospora caninum, e verificar possíveis associaçóes entre o sexo dos animais e a prevalência de anticorpos. Os soros foram analisados pelo testes de imunofluorescência indireta, considerando as diluiçóes 1:64 (T.gondii) e 1:50 (N. caninum) como pontos de corte. A prevalência de anticorpos anti-T. gondii foi de 36,2\% (47/130) (IC 95\% = 27,9 - 45,0\%) com títulos variando de 64 a 2.048, e anti- $N$. caninum de 3,1\% (4/130) (IC 95\% = 0,8 - 7,7\%) com títulos variando de 50 a 6.400. Três das quatro amostras positivas para anticorpos anti- $N$. caninum também foram positivas para anticorpos anti-T. gondii. Todos os animais positivos na RIFI para Neospora e Toxoplasma também foram positivos nas técnicas confirmatórias de immunoblotting usando antígenos totais e purificados de taquizoítos de $N$. caninum e T. gondii, ou seja, p38 (NcSRS2) e p30 (TgSAG1). Não houve associação entre o sexo dos animais e a prevalência de anticorpos anti-T. gondii e anti- $N$. caninum. Essa é a primeira indicação de infecção natural por $N$. caninum em suínos do Brasil.

Palavras-chave: Suínos, Toxoplasma gondii, Neospora caninum, soroprevalência, Nordeste do Brasil.

\footnotetext{
*Corresponding author: Solange Maria Gennari

Departamento de Medicina Veterinária Preventiva e Saúde Animal,

Faculdade de Medicina Veterinária e Zootecnia,

Universidade de São Paulo - USP, Av. Prof. Dr. Orlando Marques de Paiva, 87,

CEP 05508-270, São Paulo - SP, Brazil;

e-mail: sgennari@usp.br
} 


\section{Introduction}

The production and productivity indices of swine herds can be influenced by several conditions including genetic, environmental, nutritional, toxic, management, and infectious factors. Among parasitic diseases, toxoplasmosis occupies an important position. Toxoplasmosis is a worldwide zoonosis (ACHA; SZYFRES, 2003), and its control in pigs is important for consumer protection. This infection may also affect the reproduction of sows (DUBEY; URBAN, 1990; GIRALDI et al., 1996; JUNGERSEN et al., 2001) and productivity of pigs in general and thus may play an important role in the swine industry.

It is now accepted that Neospora caninum is a significant cause of bovine abortion worldwide and, with the exception of dogs, the disease has rarely been described in other species (DUBEY; LINDSAY, 1996; DUBEY, 1999). Experimental infection of sows led to transplacental transmission of $N$. caninum (JENSEN et al., 1998) but naturally acquired porcine infection has not been described and nothing is known on its possible presence in the pig population of Brazil.

Recent surveys conducted worldwide showed that the prevalence of anti- $N$. caninum antibodies in swine is very low. Using ELISA as screening test and an immunoblotting technique as confirmatory test, one positive animal was detected among 2,041 sows from Hesse, Germany (DAMRIYASA et al., 2004). All 454 breeding sows from England and Wales were negative by IFAT (HELMICK et al., 2002). In Switzerland, seropositive frequencies of 3 and $1 \%$ were observed in sows and fattening pigs, respectively, by ELISA, however, no case was confirmed by polymerase chain reaction (PCR) (WYSS et al., 2000).

To date, no published report exists on seropositivity to T. gondii and N. caninum in pigs in the State of Paraíba. This study was conducted to determine the prevalence of anti- $T$. gondii and anti- $N$. caninum antibodies in swine slaughtered in the public slaughterhouse of Patos municipality, State of Paraíba, Northeastern Brazil.

\section{Material and Methods}

\section{Field samples}

Sera from swine slaughtered in the public slaughterhouse of Patos municipality $\left(7^{\circ} 1^{\prime} \mathrm{S}\right.$ and $\left.37^{\circ} 17^{\prime} \mathrm{W}\right)$ were analyzed. The number of samples examined was calculated taking into account the assumed prevalence for anti- $T$. gondii and anti- $N$. caninum antibodies close to $50 \%$, to maximize the sample size, and to obtain a minimal confidence of $95 \%$ and a statistical error of $10 \%$ (THRUSFIELD, 1995). Calculations were executed using EpiInfo version 6.04, resulting in a sample of 96 swine. As a matter of opportunity a total of 130 blood samples were collected during October and November 2006. In the region, swine are confinement-raised; however, in general the conditions of sanitary management are not appropriate. It was not possible to recover the husbandry/history of the pigs tested, as the animals are slaughtered without identification.

Blood was collected before slaughter from the Vena cava cranialis into sterile vacuum tubes, separated after clotting, and the sera were centrifuged and stored at $-20^{\circ} \mathrm{C}$ until analysis.

\section{IFAT}

For the detection of anti- $T$. gondii antibodies IFAT (CAMARGO, 1974) was performed considering 1:64 dilution as the cut-off point (GARCIA et al., 1999a), using RH strain tachyzoites as antigen. IFAT for $N$. caninum (PARÉ et al., 1995) was performed using 1:50 dilution as the cut-off point (LINDSAY et al., 1995); NC-1 strain of $N$. caninum cultured in bovine monocytes was used as the antigen. The conjugate used in both tests was anti-pig IgG (whole molecule, SIGMA, St. Louis, MO, USA). Positive and negative pig sera were used as controls and the positive samples were tested until the maximum dilution titer was reached.

\section{Immunoblot analyses}

The NC-1 strain of N. caninum (DUBEY et al., 1988) and the RH strain of $T$. gondii (SABIN, 1941) were maintained in Vero cell cultures and purified as previously described (SCHARES et al., 1998, 1999). Cell-culture-derived tachyzoites were frozen as a pellet at $-80{ }^{\circ} \mathrm{C}$ until used for immunoblot or antigen purification.

The surface antigens p38 (NcSRS2) and p30 (TgSAG1) of $N$. caninum and $T$. gondii, respectively, were purified by affinitychromatography (SCHARES et al., 2000) using the monoclonal antibodies mMab 4.15.15 and P30/3 (ISL, UK).

For westernblot, total-cell-culture-derived tachyzoites or purified surface antigens of $N$. caninum $\mathrm{NC}-1$ and $T$. gondii $\mathrm{RH}$ were used. The immunoblot was performed as described (SCHARES et al., 1998). Pellets of $4 \times 10^{7}$ tachyzoites or purified p38 (0.05 $\left.\mu \mathrm{g}\right)$ of $N$. caninum and $2 \times 10^{7}$ tachyzoites or purified p30 $(0.05 \mu \mathrm{g})$ of $T$. gondii were incubated in non-reducing sample buffer $(2 \%$ [w/v] sodium dodecyl sulfate [SDS], $10 \%$ [v/v] glycerol, $62 \mathrm{mM}$ TrisHCl, pH 6.8) for 1 minute $\left(94^{\circ} \mathrm{C}\right)$, separated in $12 \%(\mathrm{w} / \mathrm{v})$ SDS polyacrylamide minigels of $60 \times 70 \times 1 \mathrm{~mm}$ size, and transferred to PVDF membranes (Immobilon-P, Millipore). After the transfer, membranes were blocked using PBS-TG (PBS with $0.05 \%[\mathrm{v} / \mathrm{v}$ ] Tween 20 (Sigma) and $2 \%[\mathrm{v} / \mathrm{v}]$ liquid fish gelatin [Serva, Germany]) and cut into 50 strips and examined as described below.

To detect antibodies against $N$. caninum tachyzoite antigens, the incubation of westernblot strips was performed as previously described (SCHARES et al., 1998), with a few modifications. Sera were diluted 1:50 in PBS-TG. Serum of an experimentally $N$. caninum-infected swine $\left(2.5 \times 10^{6}\right.$ tachyzoites i.m., isolate SweB1) (JENSEN et al., 1998), kindly provided by Prof. Peter Lind (Department of Veterinary Diagnostics and Research, Section of Immunology and Parasitology, Copenhagen, Denmark), was used as a positive control.

Based on previous studies (reviewed in DUBEY; SCHARES, 2006), only reactions with antigens of $29,30,33$, and $37 \mathrm{kDa}$ $\mathrm{Mr}$ were regarded to be specific for the interpretation of the $N$. caninum immunoblot using total tachyzoite antigens. In the $N$. caninum immunoblot using purified p38 (NcSRS2), the reactivity of sera with a single band of $38 \mathrm{kDa} \mathrm{Mr}$ was regarded a positive reaction.

To detect antibodies against $T$. gondii tachyzoite antigens, the incubation of westernblot strips was performed as described for $N$. caninum. Sera were diluted 1:10 in PBS-TG. We used a serum of a swine experimentally infected with $10^{4} T$. gondii Me49, i.v. 
(kindly provided by Dr. Christian Bauer, Institute for Parasitology, Justus Liebig University Giessen, Germany) as a positive control. Based on the previous results (HUSKINSON et al., 1989) in this test, only the reactions against three immunodominant antigens of about 20,30 , and $35 \mathrm{kDa}$ were regarded to be specific. In the $T$. gondii immunoblot using purified p30 (TgSAG1), the reactivity of sera with a single band of $30 \mathrm{kDa} \mathrm{Mr}$ was regarded as a positive reaction.

In all immunoblots, peroxidase conjugated "Affini Pure" goat anti-swine IgG $(\mathrm{H}+\mathrm{L})$ (Jackson Immunoresearch Laboratories, West Grove, PA, USA) was used diluted 1:250 in PBS-TG.

\section{Statistics}

The prevalence of anti-T. gondii and anti- $N$. caninum antibodies was estimated from the ratio of positive results to the total number of swine examined, with the exact binomial confidence interval of 95\% (THRUSFIELD, 1995), using the program EpiInfo, version 6.04. Positive associations between sex of the animals and $T$. gondii and $N$. caninum antibody seroprevalence were verified by Chi-square test $\left(\chi^{2}\right)$ or by Fisher exact test (ZAR, 1999), with a significance level of $5 \%$.

\section{Results}

For $T$. gondii, from 130 tested samples, 47 were positive (IFAT $\geq 1: 64)$, resulting in a seroprevalence of $36.2 \%(95 \%$ $\mathrm{CI}=27.9-45.0 \%)$ as presented in Table 1 . In male pigs, the seroprevalence was $37.8 \%(95 \% \mathrm{CI}=23.8-53.5 \%)$ and in female $35.3 \%$ (95\% CI $=25.2-46.4 \%)$. There was no association between sex and prevalence of anti- $T$. gondii antibodies $(\mathrm{p}=0.92)$. Overall, eight $(6.2 \%)$, seven $(5.4 \%), 10(7.7 \%), 16(12.3 \%)$, five $(3.8 \%)$, and one $(0.8 \%)$ of the animals were seropositive at reciprocal titers of $64,128,256,512,1,024$, and 2,048, respectively (Table 2).

For $N$. caninum, from 130 tested samples, four were positive (IFAT $\geq 1: 50)$, resulting in a seroprevalence of 3.1\% (95\% $\mathrm{CI}=0.8-7.7 \%$ ) (Table 1$)$. In male pigs, the seroprevalence was $2.2 \%(95 \% \mathrm{CI}=0.1-11.8 \%)$ and in female $3.5 \%(95 \%$ $\mathrm{CI}=0.7-10.0 \%)$ and no association between sex and prevalence was observed ( $\mathrm{p}=1.00)$. Overall, two $(1.5 \%)$, one $(0.8 \%)$, and one $(0.8 \%)$ pigs were seropositive at reciprocal titers of 50,200 , and 6,400 , respectively (Table 2). Three of the four $N$. caninum-positive sows were also $T$. gondii positive, all with titers of 1:512.

All the four $N$. caninum IFAT-positive samples and three $N$. caninum IFAT-negative samples $(<1: 50)$ were examined by immunoblotting. In contrast to two negative sera (Figure 1a lanes 5, 6), all positive sera (Figure 1a - lanes 1, 2, 3, 4) recognized immunodominant antigens in the $N$. caninum total tachyzoite antigen. Two $N$. caninum IFAT-positive sera reacted with three immunodominant antigens of 29,33 , and $37 \mathrm{kDa}$; two other $N$. caninum IFAT-positive sera recognized the immunodominant antigen of $37 \mathrm{kDa}$. One $N$. caninum IFAT-negative serum showed faint reactions with a $30 \mathrm{kDa} N$. caninum antigen (Figure $1 \mathrm{a}$ - lane 7). To confirm the specificity of the reactions, purified p38 antigen of $N$. caninum was also probed. In contrast to the $N$. caninum IFAT-negative sera, all of the $N$. caninum IFAT-positive sera reacted with this antigen (Figure $1 \mathrm{~b}$ ).
Table 1. Prevalence of anti-Toxoplasma gondii and anti-Neospora caninum antibodies by IFAT in 130 swine slaughtered in the municipal public slaughterhouse of Patos, Paraíba State, Northeastern Brazil, by sex.

\begin{tabular}{|c|c|c|c|c|c|c|c|}
\hline \multirow[t]{2}{*}{ Sex } & \multirow[t]{2}{*}{$\begin{array}{c}\text { No. of } \\
\text { pigs }\end{array}$} & \multicolumn{3}{|c|}{$\begin{array}{c}\text { Prevalence of } \\
\text { anti- } T \text {. gondii } \\
\text { antibodies }\end{array}$} & \multicolumn{3}{|c|}{$\begin{array}{c}\text { Prevalence of } \\
\text { anti- } N \text {. caninum } \\
\text { antibodies }\end{array}$} \\
\hline & & No. & $\%$ & 95\% CI (\%) & No. & $\%$ & $95 \%$ CI (\%) \\
\hline Male & 45 & 17 & 37.8 & $23.8-53.5$ & 1 & 2.2 & $0.1-11.8$ \\
\hline Female & 85 & 30 & 35.3 & $25.2-46.4$ & 3 & 3.5 & $0.7-10.0$ \\
\hline Total & 130 & 47 & 36.2 & $27.9-45.0$ & 4 & 3.1 & $0.8-7.7$ \\
\hline
\end{tabular}

Table 2. Prevalence of anti- $T$. gondii and anti-N. caninum antibodies by IFAT in 130 sera from swine slaughtered in the municipal public slaughterhouse of Patos, Paraíba State, Northeastern Brazil, by serum dilution.

\begin{tabular}{|c|c|c|c|c|c|}
\hline \multicolumn{3}{|c|}{ T. gondii } & \multicolumn{3}{|c|}{ N. caninum } \\
\hline $\begin{array}{c}\text { Reciprocal } \\
\text { titer }\end{array}$ & $\begin{array}{c}\text { No. of } \\
\text { positive } \\
\text { pigs }\end{array}$ & $\begin{array}{c}\text { Prevalence } \\
(\%)\end{array}$ & $\begin{array}{c}\text { Reciprocal } \\
\text { titer }\end{array}$ & $\begin{array}{c}\text { No. of } \\
\text { positive } \\
\text { pigs }\end{array}$ & $\begin{array}{c}\text { Prevalence } \\
(\%)\end{array}$ \\
\hline 64 & 8 & 6.2 & 50 & 2 & 1.5 \\
\hline 128 & 7 & 5.4 & 200 & 1 & 0.8 \\
\hline 256 & 10 & 7.7 & 6,400 & 1 & 0.8 \\
\hline 512 & 16 & 12.3 & & & \\
\hline 1,024 & 5 & 3.8 & & & \\
\hline 2,048 & 1 & 0.8 & & & \\
\hline Total & 47 & 36.2 & & 4 & 3.1 \\
\hline
\end{tabular}

When all samples were probed with total $T$. gondii antigen the three $N$. caninum and $T$. gondii IFAT-positive samples and one negative control serum reacted with immunodominant antigens of $T$. gondii of $30 \mathrm{kDa}$ (4/4 sera), $20 \mathrm{kDa}$ (2/4 sera), and $35 \mathrm{kDa}(2 / 2$ sera) (Figure $1 \mathrm{c}$ - lanes 1, 3, 4, 5). All of these sera also reacted with the purified p30 antigen of $T$. gondii tachyzoites (Figure 1d - lanes 1, 3, 4, 5). One of the $N$. caninum IFAT-positive sera was only $N$. caninum but not $T$. gondii positive in the immunoblot analyses as previously determined by IFAT (Figure 1c and 1d - lane 2).

\section{Discussion}

This is the first survey to give indication on the presence of $N$. caninum antibodies in pigs in Brazil.

The occurrence of $T$. gondii antibodies of $36.2 \%$ is in the range of the values found in other studies from Brazil with adult pigs (8.54 to 90.4\%) (GUIMARÁES et al., 1992; GARCIA et al., 1999b; CAVALCANTE et al., 2006; MOURA et al., 2007; MILLAR et al., 2008).

As the samples were obtained from slaughtered animals, the only available information was on the sex of the pigs. No association was observed when sex was compared with seroprevalence of $N$. caninum and T. gondii antibodies.

Toxoplasma gondii antibody titers were higher than observed in sows from Germany, where $73 \%$ of the reactive samples presented 
titers of $1: 16$, just above the cut-off value used in their assay (DAMRIYASA et al., 2004). However, other Brazilian studies using the same method as the present study (IFAT) also found higher titer values (GARCIA et al., 1999b; CAVALCANTE et al., 2006).

In studies conducted in Hesse, Germany (DAMRIYASA et al., 2004), sows responding to Sarcocystis miescheriana antigen were found to be more frequently $T$. gondii positive $(21 \%)$ than Sarcocystis-negative animals (16.9\%). There were no studies using sera from Brazilian pigs testing the presence of antibodies to other related coccidian parasites and cross reactivity with $T$. gondii. This might be of epidemiological importance and requires further investigation.

Concerning N. caninum, 3.1\% (four samples) were positive by IFAT $(\geq 50)$ and three of them were also $T$. gondii positive by IFAT. To confirm the specificity of our IFAT results we employed four western blotting techniques, using total and purified antigens of $N$. caninum and $T$. gondii.

For cattle it is well established that $T$. gondii-infected animals show only limited cross-reactions with non-reduced immunodominant $N$. caninum tachyzoite antigens (STAUBLI et al., 2006) and with the native, immunopurified $38 \mathrm{kDa}$ (NcSRS2) antigen (SCHARES et al., 1999; SCHARES et al., 2000). All $N$. caninum IFAT-positive sera recognized immunodominant
$N$. caninum antigens and the purified $38 \mathrm{kDa}$ antigen (Figure $1 \mathrm{a}$, 1 b - lanes 1-4). However, three of these four $N$. caninum-positive sera also reacted with immunodominant $T$. gondii antigens and with the $30 \mathrm{kDa}$ antigen of $T$. gondii (Figure 1c, $1 \mathrm{~d}$ - lanes 1, 3, 4). This suggests that three of four pigs were infected with both $N$. caninum and T. gondii.

One $N$. caninum IFAT- and immunoblot-negative serum also showed clear reactions with immunodominant $T$. gondii antigens and with the $30 \mathrm{kDa}$ antigen of $T$. gondii (Figure 1c, 1d - lane 5). However, this serum did not react with either $N$. caninum total immunodominant antigens or the $38 \mathrm{kDa}$ antigen, thus confirming the specificity of our IFAT results. When the samples were probed with total $T$. gondii antigen, the sample that was $N$. caninum IFAT-positive and $T$. gondii IFAT-negative was the only negative in the immunoblot analyses (Figure 1c, 1d - lane 2), also confirming the specificity of our IFAT results.

Consequently, similar to the findings of others (DAMRIYASA et al., 2004) our serological results suggest that only low numbers of pigs seem to be naturally infected with $N$. caninum. However, the final proof of natural $N$. caninum infection in pigs is lacking and can only be achieved by isolating viable $N$. caninum from swine. Nevertheless, our results show that further studies are necessary to elucidate a potential effect of $N$. caninum on reproduction in swine.
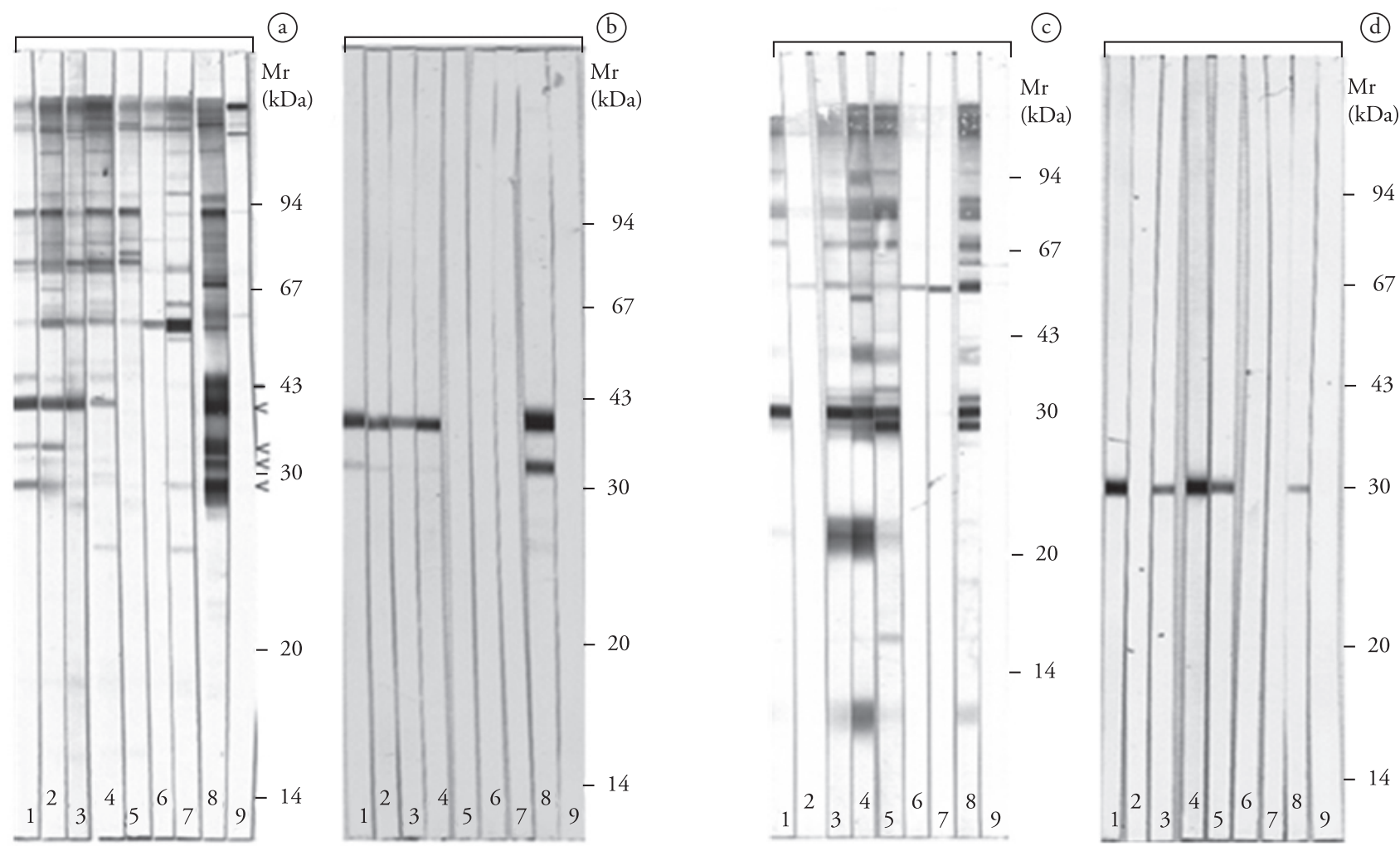

Figure 1. Immunoblotting analyses of four Neospora caninum-positive samples (Lanes 1 - 4) with IFAT titers of 1:50 (lanes 1 and 2), 1:200 (lane 3), and 1:6400 (lane 4); and three N. caninum-negative samples (lanes 5-7), with IFAT titers $<1: 50$. Sera were probed with total $N$. caninum antigen (a), purified $N$. caninum p38 (NcSRS2) (b), total T. gondii antigen (c), and purified T. gondii p30 (tgSAG1) (d). The position of immunodominant antigens is marked by $(<)$. In contrast to two negative sera, all $N$. caninum IFAT-positive sera recognized immunodominant antigens of $N$. caninum. One of these sera was negative for antibodies against $T$. gondii (lane 2). Another serum was positive for T. gondii but negative for $N$. caninum (lane 5). N. caninum controls: positive (a and b, lane 8), negative (a and b, lane 9). Toxoplasma gondii controls: positive (c and d, lane 8), negative (c and d, lane 9). 


\section{Acknowledgments}

To Conselho Nacional de Pesquisa (CNPq), Brazil, for the fellowship to S. M. Gennari; to Professor Peter Lind (Department of Veterinary Diagnostics and Research, Section of Immunology and Parasitology, Copenhagen, Denmark) for providing Neospora-positive swine serum; to Dr. Christian Bauer (Institute for Parasitology, Justus Liebig University Giessen, Giessen, Germany) for providing Toxoplasma-positive swine serum; and to Andrea Bärwald for technical assistance.

\section{References}

ACHA, P. N.; SZYFRES, B. Zoonosis y enfermidades transmissibles comunes al hombre y a los animales parasitosis. 3. ed. Washington, DC: Organizacion Panamericana de La Salud, 2003. 424 p.

CAMARGO, M. E. Introdução às técnicas de imunofluorescência. Revista Brasileira de Patologia Clínica, v. 10, n. 3, p. 143-171, 1974.

CAVALCANTE, G. T. et al. Seroprevalence of Toxoplasma gondii antibodies in cats and pigs from rural western Amazon, Brazil. Journal of Parasitology, v. 92, n. 4, p. 863-864, 2006.

DAMRIYASA, I. M. et al. Cross-sectional survey in pig breeding farms in Hesse, Germany: seroprevalence and risk factors of infections with Toxoplasma gondii, Sarcocystis spp. and Neospora caninum in sows. Veterinary Parasitology, v. 126, n. 3, p. 271-286, 2004.

DUBEY, J. P. et al. Neonatal Neospora caninum infection in dogs: isolation of the causative agent and experimental transmission. Journal of the American Veterinary Medical Association, v. 193, n. 10, p. 1259-1263, 1988.

DUBEY, J. P. Recent Advances in Neospora and neosporosis. Veterinary Parasitology, v. 84, n. 3-4, p. 349-367, 1999.

DUBEY, J. P.; LINDSAY, D. S. A review of Neospora caninum and neosporosis. Veterinary Parasitology, v. 67, n. 1-2, p. 1-59, 1996

DUBEY, J. P.; SCHARES, G. Diagnosis of bovine neosporosis. Veterinary Parasitology, v. 140, n. 1-2, p. 1-34, 2006.

DUBEY, J. P.; URBAN, J. F. Diagnosis of transplacentally induced toxoplasmosis in pigs. American Journal of Veterinary Research, v. 51, n. 8, p. 1295-1299, 1990.

GARCIA, J. L. et al. Soroepidemiologia da toxoplasmose em gatos e cães de propriedades rurais do município de Jaguapitã, estado do Paraná, Brazil. Ciência Rural, v. 29, n. 1, p. 99-104, 1999a.

GARCIA, J. L. et al. Soroprevalência do Toxoplasma gondii em suínos, bovinos, ovinos e eqüinos, e sua correlação com humanos, felinos e caninos, oriundos de propriedades rurais do norte do Paraná - Brasil. Ciência Rural, v. 29, n. 1, p. 91-97, 1999 b.

GIRALDI, N. et al. Estudo da toxoplasmose congênita natural em granjas de suínos em Londrina, PR. Arquivo Brasileiro de Medicina Veterinária e Zootecnia, v. 48, n. 1, p. 83-90, 1996.

GUIMARÃES, A. M. et al. Freqüência de anticorpos anti-Toxoplasma gondii em suínos da raça Piau. Arquivo Brasileiro de Medicina Veterinária e Zootecnia, v. 44, n. 1, p. 69-71, 1992.
HELMICK, B. et al. Serological investigation of aborted sheep and pigs for infection by Neospora caninum. Research in Veterinary Science, v. 73, n. 2, p. 187-189, 2002.

HUSKINSON, J. et al. Toxoplasma antigens recognized by immunoglobulin G subclasses during acute and chronic infection. Journal of Clinical Microbiology, v. 27, n. 9, p. 2031-2038, 1989.

JENSEN, L. et al. Experimental porcine neosporosis. Acta Pathologica, Microbiologica et Immunologica Scandinavica, v. 106, n. 4 , p. 475-482, 1998.

JUNGERSEN, G. et al. Transplacental transmission of Toxoplasma gondii in minipigs infected with strains of different virulence. Journal of Parasitology, v. 87, n. 1, p. 108-113, 2001.

LINDSAY, D. S. et al. Abortions, fetal death, and stillbirths in pregnant pygmy goats inoculated witch tachyzoites of Neospora caninum. American of Journal of Veterinary Research, v. 56, p. 1176-1180, 1995.

MILLAR, P. R. et al. Toxoplasma gondii: estudo soro-epidemiológico de suínos da região sudoeste do estado do Paraná. Pesquisa Veterinária Brasileira, v. 28, n. 1, p. 15-18, 2008.

MOURA, A. B. et al. Ocorrência de anticorpos contra Toxoplasma gondii em suínos e ovinos abatidos no município de Guarapuava, PR, Brasil. Revista Brasileira de Parasitologia Veterinária, v. 16, n. 1, p. 54-56, 2007 .

PARÉ, J.; HIETALA, S. K.; THURMOND, M. C. Interpretation of an indirect fluorescent antibody test for diagnosis of Neospora sp. infection in cattle. Journal of Veterinary Diagnostic Investigation, v. 7, n. 2, p. 273-275, 1995.

SABIN, A. B. Toxoplasmic encephalitis in children. Journal of the American Medical Association, v. 116, n. 9, p. 801-807, 1941.

SCHARES, G. et al. Neospora caninum: identification of 19-, 38-, and $40-\mathrm{kDa}$ surface antigens and a $33-\mathrm{kDa}$ dense granule antigen using monoclonal antibodies. Experimental Parasitology, v. 92, n. 2, p. 109-119, 1999.

SCHARES, G. et al. The efficiency of vertical transmission of Neospora caninum in dairy cattle analysed by serological techniques. Veterinary Parasitology, v. 80, n. 2, p. 87-98, 1998.

SCHARES, G. et al. Use of purified tachyzoite surface antigen p38 in an ELISA to diagnose bovine neosporosis. International Journal of Parasitology, v. 30, n. 10, p. 1123-1130, 2000.

STAUBLI, D. et al. Neospora caninum immunoblotting improves serodiagnosis of bovine neosporosis. Parasitology Research, v. 99, n. 6 , p. $648-658,2006$.

THRUSFIELD, M. Veterinary epidemiology. 2. ed. Cambridge: Blackwell Science, 1995. 479 p.

WYSS, R. et al. Untersuchungen zum vorkommen von Toxoplasma gondii und Neospora caninum unter fleischhygienischen Aspekten. Schweiz Archieves Tierheilk, v. 142, p. 95-108, 2000.

ZAR, J. H. Biostatistical analysis. 4. ed. Upper Saddle River: Prentice Hall, 1999. 663 p. 